\title{
Bioelectricity production from tofu wastewater using microbial fuel cells with microalgae Spirulina sp as catholyte
}

\author{
Wahyu Zuli Pratiwi ${ }^{1,2^{*}}$, Hadiyanto Hadiyanto ${ }^{1,2}$, Purwanto Purwanto ${ }^{2}$, Muthi'ah Nur \\ Fadlilah $^{1,2}$ \\ ${ }^{1}$ Center of of Biomass and Renewable Energy (CBIORE), Diponegoro University, Indonesia \\ ${ }^{2}$ Department of Chemical Engineering, Faculty of Engineering, Diponegoro University, Semarang, \\ Indonesia
}

\begin{abstract}
Microalgae-Microbial Fuel Cells (MMFCs) are very popular to be used to treat organic waste. MMFCs can function as an energy-producing wastewater pre-treatment system. Wastewater can provide an adequate supply of nutrients, support the large capacity of biofuel production, and can be integrated with existing wastewater treatment infrastructure. The reduced content of Chemical Oxygen Demand (COD) is one way to measure the efficiency of wastewater treatment. MMFCs reactors are made in the form of two chambers (anode and cathode) both of which are connected by a salt bridge. Tofu wastewater as an anode and Spirulina $s p$ as a cathode. To improve MFCs performance which is to obtain maximum COD removal and electricity generation, nutrient $\mathrm{NaHCO}_{3}$ as the nutrient carbon source for Spirulina $s p$ was varied. The system running phase on 12 days. The results were Spirulina $s p$ treated with MFCs technology has better growth than nonMFCs. The MMFC generated a maximum power density of $21.728 \mathrm{~mW} / \mathrm{cm}^{2}$ and achieved $57.37 \%$ COD removal. These results showed that the combined process was effective in treating tofu wastewater.
\end{abstract}

Keywords: Microalgae-Microbial Fuel Cells, Tofu wastewater, Spirulina $s p$, Chemical Oxygen Demand, Power density

\section{INTRODUCTION}

Tofu wastewater is the biggest and has the potential pollute to the environment [1]. Organic material contained in tofu liquid waste that encourages the rapid growth of microbes in water and results in a decrease in levels oxygen in the water. Tofu wastewater also contains suspended materials, resulting in increased water turbidity[2]. Tofu wastewater from industry is available in large quantities in Indonesia. The level of consumption of tofu in Indonesia reached $7.4 \mathrm{~kg} /$ person / year. Dianursanti et al [3] states that data obtained from BPPT (Agency for Assessment and Application of Technology) shows that for every $80 \mathrm{~kg}$ of tofu produced, $2610 \mathrm{~kg}$ of waste is produced.

\footnotetext{
*Corresponding author: wahyuzulip@gmail.com
} 
On the other study from [4]reported that electrolytes contained in wastewater were identified as elements needed to improve the generation of electrical efficiency in MFCs. Microbial Fuel Cells (MFCs) are a tool that is able to convert chemical energy into electrical energy through biological pathways with the help of microorganisms [5]. The several studies have integrated microalgae in MFCs as Microalgae-Microbial Fuel Cells [6-10].

The process of photosynthesis of microalgae can be used to convert solar energy into electricity through simultaneous metabolic reactions with bacteria[11]. Through the photosynthesis process, microalgae require $\mathrm{CO}_{2}$ as a source to produce biomass[12]. Biological methods of $\mathrm{CO}_{2}$ absorption using green microalgae and cyanobacteria are considered the most potential methods [13].

Adamczyk et al [14] reported that each species of microalgae has the advantage of absorbing carbon dioxide. Shurair et al [15] on their research have conducted microalgae culture trials with treatments different $\mathrm{CO}_{2}$ supply and different operational temperatures. The results of this study indicate that Spirulina $s p$ microalgae-based wastewater is successfully used as a $\mathrm{CO}_{2}$ capture technology.

The $\mathrm{CO}_{2}$ content is a source of carbon for the process of photosynthesis of microalgae, increasing the density of Spirulina $s p$. caused by the availability of sufficient $\mathrm{CO}_{2}$ in the environment so that the metabolic process takes place quickly. In MMFCs, ideally when all $\mathrm{CO}_{2}$ produced by anodic biofilms can be consumed by microalgae cells in the cathodic space, while all $\mathrm{O}_{2}$ produced can be presented as electron acceptors needed for cathodic chamber [16].

MMFCs system performance is influenced by many factors including the growth of the microalgae. One of the factors that influence the growth of microalgae is the change in available carbon, which can determine the photosynthesis process [17].

To realize this bicarbonate-based approach, this study demonstrates the ability of Spirulina sp microalgae to utilize bicarbonate as a source carbon and determine the optimal culture conditions with bicarbonate. In addition, the potential benefits of using $\mathrm{NaHCO}_{3}$, reveal that bicarbonate can be more beneficial than raw exhaust gas or monoethanolamine (MEA) extracted pure $\mathrm{CO}_{2}$ in connection with net $\mathrm{CO}_{2}$ emissions and productivity of algae biomass. All this supports that the cultivation of microalgae Spirulina sp. based bicarbonate is indeed feasible and practical, especially when integrated with MMFCs technology

\section{MATERIALS AND METHODS}

The research is conducted in the C-BIORE integrated laboratory of Diponegoro University,Semarang.

\subsection{Microalgae-Microbial Fuel Cells (MMFCs)}

The MMFCs system model used refers to[18] which is modified. The design of MMFCs consisted of dual-chamber with volume $1 \mathrm{~L}$ for each chamber separated by a salt bridge. The salt bridge is made out of $\mathrm{KCl}$ with agar dilute on aquadest [19]. The concentration of KCL $3 \mathrm{M}$. The two graphite electrodes were used in both anode and cathode. The lenght and diameter of electrode was $10 \mathrm{~cm}$ and $1 \mathrm{~cm}$ respectively. The electrode should be remove from impurities by soaking in $1 \mathrm{M} \mathrm{HCl}$ followed $1 \mathrm{M} \mathrm{NaOH}$ solutions for 24 hours and then rinsing them with DI water. Microalgae Spirulina sp was obtained from PT Algae Park Indonesia Mandiri (Solo). The aerator pump was connected to the cathode chamber to homogenize the microalgae Spirulina sp culture. A small rubber hose is placed between the anode chamber and the cathode chamber as a link for $\mathrm{CO}_{2}$ gas transfer. Tofu wastewater is obtained in the tofu industry in Semarang. MMFCs then tightly closed, and each electrode in the chamber 
was connected by a cable. The two wires connected by a multimeter (Spardio SP-9205A) to measure the voltage and current. The system running phase of MMFCs on 12 days.

\subsection{Optical Density}

The growth microalgae Spirulina $s p$ was controlled by measuring the optical density (OD), which is The at the wavelength $680 \mathrm{~nm}$ was. The research was carried out using a UV-VIS Spectroquant Prove 100.

\subsection{Chemical Oxygen Demand (COD)}

COD of tofu wastewater measured in real-time with COD analysers (HI 83099)

\section{RESULTS AND DISCUSSION}

Tofu wastewater characteristics

The characteristics analysis of the wastewater to determine the initial concentration of the parameters studied.

Table 2. Characteristics of the influent tofu wastewater

\begin{tabular}{ccc}
\hline Parameters & $\begin{array}{c}\text { Measurement } \\
\text { result }\end{array}$ & Unit \\
\hline Temperature & 25 & ${ }^{\circ} \mathrm{C}$ \\
$\mathrm{pH}$ & 3.41 & - \\
Chemical oxygen demand (COD) & $6285 \pm 70$ & $\mathrm{mg} \bullet \mathrm{L}-1$ \\
\hline
\end{tabular}

Based on the results of the initial characteristics test on tofu wastewater, it can be seen that the value of COD is still high and not in accordance with the quality standards of tofu wastewater listed in the Central Java provincial regulation number 5 of 2012 is the maximum permissible COD level is $275 \mathrm{mg}$. $\mathrm{L}^{-1}$.

\subsection{Microalgae Spirulina sp Growth}

Fig. 1 shows the Spirulina $s p$ growth added to the cathode side of MFCs with $\mathrm{NaHCO}_{3}$ nutrient treatments are different. As a comparison used cultivation of Spirulina sp non MFCs, it can be seen that Spirulina sp experiences a typical growth curve consisting of the lag phase, extended exponential growth phase and stationary phase. On the other hand, giving a dose of $\mathrm{NaHCO}_{3}$ as much as $5 \mathrm{gr}$. L-1 at run 2 indicates the growth rate faster. The experimental results show that Optical Density (OD) increases with time for both treatments. The biomass concentration is associated with an increase in dissolved oxygen concentration.

$\mathrm{NaHCO}_{3}$ is a source of carbonate that can be converted to $\mathrm{CO}_{2}$ plays a role in the photosynthetic process of microalgae spirulina $s p$. The reaction of photosynthetic are :

$$
6 \mathrm{CO}_{2}+12 \mathrm{H}_{2} \mathrm{O}+\mathrm{h} v \text { (light energy) } \rightarrow \mathrm{C}_{6} \mathrm{H}_{12} \mathrm{O}_{6}+6 \mathrm{O}_{2}+6 \mathrm{H}_{2} \mathrm{O}
$$

Therefore, microalgae Spirulina sp able to utilize bicarbonate ion $\left(\mathrm{HCO}_{s^{-}}\right)$or carbon dioxide as a source of carbon in its photosynthesis, with the help of an enzyme called carbonic anhydrite [20]. 
To investigate the effect of $\mathrm{CO}_{2}$ sources on MMFCs on the growth ofmicroalgae Spirulina $s p, \mathrm{CO}_{2}$ gas produced from the anode chamber containing tofu waste is channeled through a transparent hose to the cathode chamber. The anolyte and catholyte conditions were maintained the same as before. By applying the MMFCs system, the substrate is oxidized at the anode and uses algal biocatodes which act as biological electron acceptors simultaneously reducing $\mathrm{CO}_{2}$ to biomass. Autotrophic and heterotrophic metabolism in microalgae Spirulina $s p$ create conditions where all types of $\mathrm{CO}_{2}$ (atmospheric and organic) can be consumed [21].

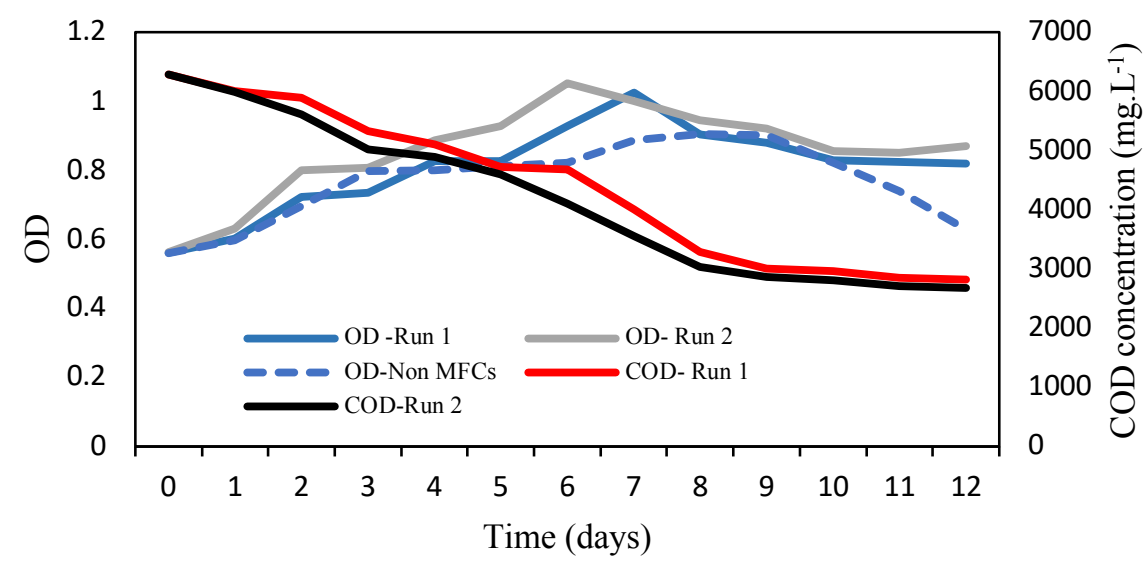

Fig. 1. Density Optical of Spirulina $s p$ and COD concentrations decline with the addition of NaHCO3 nutrient as a variation.

\subsection{The influence of performance MFCs to decreased levels of Chemical Oxygen Demand (COD) on tofu wastewater}

Decreased levels of COD that occurs in the reactor MFCs caused by the activities of microorganisms which decomposes organic matter in the anode compartment of tofu wastewater which is used as a substrate for MFCs, shows a decrease in the organic load contained in the waste. The decrease occurs differently in each treatment. The results of the COD analysis can be seen in Fig.1.

The lowest COD value is found in the run- 1 treatment amounted to $2820 \mathrm{mg}$. L-1 on the $12^{\text {th }}$ day. As for the treatment run 2, the COD value obtained on the $12^{\text {th }}$ day was $2679 \mathrm{mg} \mathrm{L}$ 1. Then the percent removal value of COD was $55.13 \%$ for run 1 and $57.37 \%$ for run 2 . However, based on the ANOVA analysis that had been done the results showed that the difference in COD did not provide a significantly different difference in the treatment of different amounts of $\mathrm{NaHCO}_{3}$ added to the cathode chamber.

Christwardana et al [22] reported that by using the MMFCs system that utilizes microalgae Spirulina sp. percent COD removal up to $60 \%$. Hadiyanto et al [23] reported that the percent value of COD removal reached $67 \%$ in tapioca wastewater that was configured to MFCs aided by microalgae Spirulina $s p$.

\subsection{Power density of MMFCs}

The operation of the MMFCs system was carried out using microalgae Spirulina sp in the cathode chamber. The power density generated in the MMFCs system is presented in Fig. 2. 


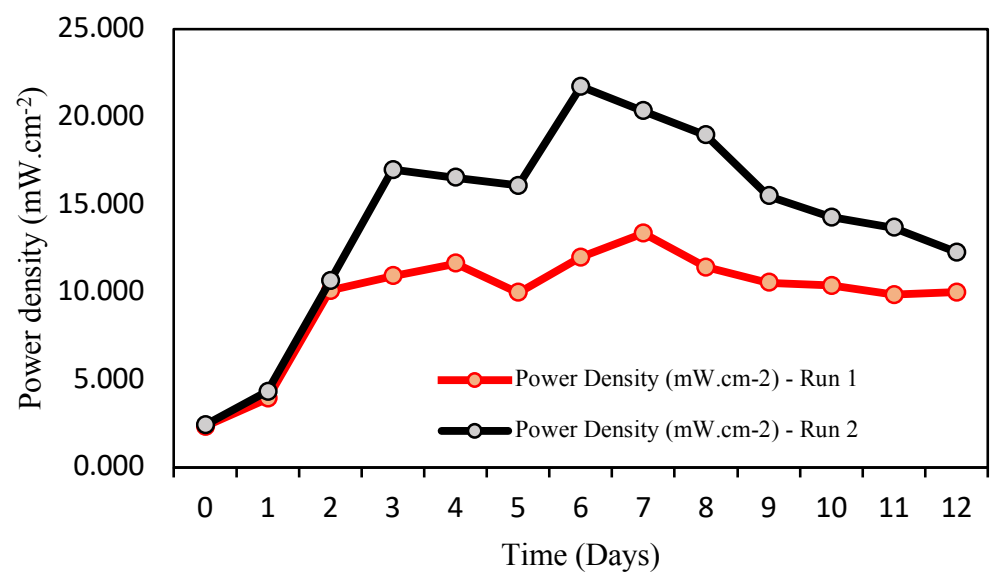

Fig. 2. Power Density of MMFCs

Based on Fig. 2 it can be seen that electricity production has decreased on day 5", fluctuations from the production of electricity produced are also influenced by bacteria from tofu wastewater in the anode. The result of electrical fluctuations can be caused by interactions and competition from bacteria that live in the growth substrate. The highest power density that can be achieved is $21,728 \mathrm{~mW} . \mathrm{cm}^{-2}$ with voltage and current are $2.7 \mathrm{mV}$ and $518 \mathrm{~mA}$ respectively. On the MMFCs system of the variable (run-1 and run-2) have an increased in power density at 6 days. This shows that microbial metabolism increased sharply because of the large number of organic compounds that can be consumed by microbes so that energy is fulfilled. Power density is proportional to the level of the substrate[24]. Each variable (run-1 or run-2) power density has decreased on the $8^{\text {th }}$ day until the $12^{\text {th }}$-day. Jiang [9] investigated that a combination of microbial fuel cells with microalgae cultivation for domestic wastewater treatment generated a maximum power density of $268.5 \mathrm{~mW} \cdot \mathrm{m}^{-2}$.

\section{CONCLUSION}

Level variations of $\mathrm{NaHCO}_{3}$ in the growth of microalgae media have affected the growth rate of Spirulina sp. As part of the conditions tested, the growth of Spirulina sp microalgae using the MFCs system gave a better response than those without MFCs. This is due to the presence of sufficient nutrients (carbon) available in the MFCs system.

MFCs system configuration with a given of dose 5 gr. $\mathrm{L}^{-1} \mathrm{NaHCO}_{3}$ in growth medium in the catholyte chamber containing microalgae Spirulina $s p$ gave better results with a maximum power density of up to $21.728 \mathrm{~mW} \mathrm{~cm}-2$. In addition, the results showed that the performance of MFCs had an effect on reducing levels of Chemical Oxygen Demand (COD) in tofu wastewater, the percentage of COD removal reached $57.37 \%$.

\section{References}

1. M. Faisal, A. Gani, F. Mulana, and H. Daimon, Treatment and utilization of industrial tofu waste in Indonesia, Asian J. Chem., vol. 28, no. 3, pp. 501-507 (2016)

2. H. Effendi, R. Seroja, and S. Hariyadi, Response surface method application in tofu production liquid waste treatment, Indones. J. Chem., vol. 19, no. 2, pp. 298-304 (2019) 
3. B. Dianursanti, T. Rizkytata, M. T. Gumelar, and T. H. Abdullah, Industrial tofu wastewater as a cultivation medium of microalgae Chlorella vulgaris, Energy Procedia, vol. 47, pp. 56-61 (2014)

4. G. S. Jadhav and M. M. Ghangrekar, Improving performance of MFC by design alteration and adding cathodic electrolytes, Appl. Biochem. Biotechnol., vol. 151, no. 2-3, pp. 319-332 (2008)

5. S. B. Velasquez-Orta, T. P. Curtis, and B. E. Logan, Energy from algae using microbial fuel cells, Biotechnol. Bioeng., vol. 103, no. 6, pp. 1068-1076 (2009)

6 W. Logroño et al., Single chamber microbial fuel cell (SCMFC) with a cathodic microalgal biofilm: A preliminary assessment of the generation of bioelectricity and biodegradation of real dye textile wastewater, Chemosphere, vol. 176, pp. 378-388 (2017)

7. S. A. Motto, M. Christwardana, and Hadiyanto, Potency of yeast - Microalgae spirulina collaboration in microalgae-microbial fuel cells for cafeteria wastewater treatment, IOP Conf. Ser. Earth Environ. Sci., vol. 209, no. 1, pp. 0-8 (2018)

8. H. M. Jiang, Combination of Microbial Fuel Cells with Microalgae Cultivation for Bioelectricity Generation and Domestic Wastewater Treatment, Environ. Eng. Sci., vol. 34, no. 7, pp. 489-495 (2017)

9. D. F. Juang, C. H. Lee, and S. C. Hsueh, Comparison of electrogenic capabilities of microbial fuel cell with different light power on algae grown cathode, Bioresour. Technol., vol. 123, pp. 23-29 (2012)

10. H. J. Jeon et al., Production of algal biomass (Chlorella vulgaris) using sediment microbial fuel cells, Bioresour. Technol., vol. 109, pp. 308-311 (2012)

11. H. Liu, S. Cheng, and B. E. Logan, Power generation in fed-batch microbial fuel cells as a function of ionic strength, temperature, and reactor configuration, Environ. Sci. Technol., vol. 39, no. 14, pp. 5488-5493 (2005)

12. J. Masojídek, G. Torzillo, and M. Koblízek, Photosynthesis in Microalgae, Handb. Microalgal Cult. Appl. Phycol. Biotechnol. Second Ed., no. April, pp. 21-36 (2013)

13. G. Markou, D. Vandamme, and K. Muylaert, Microalgal and cyanobacterial cultivation: The supply of nutrients, Water Res., vol. 65, pp. 186-202 (2014)

14. M. Adamczyk, J. Lasek, and A. Skawińska, CO2 Biofixation and Growth Kinetics of Chlorella vulgaris and Nannochloropsis gaditana, Appl. Biochem. Biotechnol., vol. 179, no. 7, pp. 1248$1261(2016)$

15. M. S. Shurair, F. Almomani, S. Judd, R. R. Bhosale, and A. Kumar, Potential for green algae spirulina to capture carbon dioxide from gas stream, Adv. Mater. - TechConnect Briefs, vol. 2, no. May, pp. 141-143 (2016).

16. D. J. Lee, J. S. Chang, and J. Y. Lai, Microalgae-microbial fuel cell: A mini review, Bioresour. Technol., vol. 198, pp. 891-895 (2015)

17. R. A. Soni, K. Sudhakar, and R. S. Rana, Spirulina - From growth to nutritional product: A review, Trends Food Sci. Technol., vol. 69, no. September, pp. 157-171 (2017)

18. H. Wang, L. Lu, D. Liu, F. Cui, and P. Wang, Characteristic changes in algal organic matter derived from Microcystis aeruginosa in microbial fuel cells, Bioresour. Technol., vol. 195, pp. 25-30 (2015)

19. M. R. Khan, R. Bhattacharjee, and M. S. A. Amin, Performance of the Salt Bridge Based Microbial Fuel Cell, Int. J. Eng. Technol., vol. 1, no. 2, p. 115 (2012)

20. R. Muñoz and B. Guieysse, Algal-bacterial processes for the treatment of hazardous contaminants: A review, Water Res., vol. 40, no. 15, pp. 2799-2815 (2006)

21. I. Gajda, J. Greenman, C. Melhuish, and I. Ieropoulos, Photosynthetic cathodes for microbial fuel cells, Int. J. Hydrogen Energy, vol. 38, no. 26, pp. 11559-11564 (2013)

22. M. Christwardana, H. Hadiyanto, S. Anggraeni, and S. Sudarno, Biomass and Bioenergy Performance evaluation of yeast-assisted microalgal microbial fuel cells on bioremediation of cafeteria wastewater for electricity generation and microalgae biomass production, Biomass and Bioenergy, vol. 139, no. May, p. 105617 (2020) 
23. H. Hadiyanto, M. Christwardana, and C. da Costa, Electrogenic and biomass production capabilities of a Microalgae-Microbial fuel cell (MMFC) system using tapioca wastewater and Spirulina platensis for COD reduction, Energy Sources, Part A Recover. Util. Environ. Eff., vol. 00, no. 00, pp. 1-12 (2019)

24. D. F. Juang, P. C. Yang, H. Y. Chou, and L. J. Chiu, Effects of microbial species, organic loading and substrate degradation rate on the power generation capability of microbial fuel cells, Biotechnol. Lett., vol. 33, no. 11, pp. 2147-2160 (2011) 